\title{
ANALYSIS OF STUDENTS' PROBLEM SOLVING ABILITY BASED ON METACOGNITION ABILITY IN SET TOPIC
}

\author{
Riko Pardiansyah $^{1 *}$, Kamid ${ }^{2}$, Bambang Hariyadi ${ }^{3}$ \\ ${ }^{1,2,3}$ Department of Mathematic Education, Postgraduate Program, Universitas Jambi, Indonesia
}

*Corresponding author: riko6257@gmail.com

\begin{tabular}{|c|c|}
\hline Article Info & ABSTRACT \\
\hline Article history: & \multirow{6}{*}{$\begin{array}{l}\text { This mixed method research was conducted to find out how } \\
\text { students' problem-solving abilities were seen from the } \\
\text { metacognition ability on the topic set. The population in this study } \\
\text { were class XII students of MAN } 2 \text { Jambi City in the } 2020 / 2021 \\
\text { academic year. The sample in this study was selected using the } \\
\text { simple random sampling technique. The results of this study } \\
\text { indicate that students' problem solving abilities based on students' } \\
\text { metacognitive abilities on the topic of the set are in the good } \\
\text { category. Metacognition ability can make it easier for students to } \\
\text { solve mathematical problems that have been given. Metacognition } \\
\text { indicators that seem to have been mastered by students in this study } \\
\text { are awareness, regulation, and evaluation. }\end{array}$} \\
\hline 106,2021 & \\
\hline & \\
\hline Publi & \\
\hline Keywords: & \\
\hline $\begin{array}{l}\text { Metacognition ability } \\
\text { Problem solving ability } \\
\text { Sets }\end{array}$ & \\
\hline
\end{tabular}

\begin{tabular}{|c|c|}
\hline $\begin{array}{r}\text { ANALISIS KE } \\
\text { BERDASARKAN }\end{array}$ & $\begin{array}{l}\text { UAN PEMECAHAN MASALAH SISWA } \\
\text { AMPUAN METAKOGNISI PADA MATERI } \\
\text { HIMPUNAN }\end{array}$ \\
\hline & ABSTRAK \\
\hline Kata Kunci: & Penelitian ini dilakukan bertujuan untuk mengetahui bagaimana \\
\hline $\begin{array}{l}\text { Kemampuan metakognisi } \\
\text { Kemampuan pemecahan } \\
\text { masalah } \\
\text { Himpunan }\end{array}$ & $\begin{array}{l}\text { kemampuan pemecahan masalah siswa jika dilihat dari kemampuan } \\
\text { metakognisi pada materi himpunan. Penelitian ini termasuk } \\
\text { kedalam penelitian Mixed Methode. Populasi pada penelitain ini } \\
\text { adalah siswa kelas XII MAN } 2 \text { Kota Jambi tahun ajaran 2020/2021. } \\
\text { Sampel pada penelitian ini dipilih dengan menggunakan teknik } \\
\text { pengambilan sampel Simple Random Sampling. Hasil penelitian ini } \\
\text { menunjukkan bahwa kemampuan pemecahan masalah siswa } \\
\text { berdasarkan kemampuan metakognisi siswa pada materi himpunan } \\
\text { terkategori baik. Kemampuan metakognisi dapat mempermudah } \\
\text { siswa dalam menyelesaikan masalah matematika yang telah } \\
\text { diberikan. Indikator metakognisi yang muncul pada saat siswa } \\
\text { memecahkan masalah yang telah diberikan dalam hal ini adalah } \\
\text { aspek kesadaran, regulasi dan evaluasi. }\end{array}$ \\
\hline
\end{tabular}

(C) 2021 Unit Riset dan Publikasi Ilmiah FTK UIN Raden Intan Lampung

\section{INTRODUCTION}

Problem solving is one of the important skills in life because by mastering problem solving skills, students will be able to complete learning with good results. The skills that are trained through this learning are very useful for overcoming everyday problems outside of school. One of the benefits of mastering problem solving skills is that it can provide students with skills to become innovators, innovative entrepreneurs, change behavior, increase creativity and cognitive skills, be able to produce quality work, and be able to 
solve problems that arise in the working world [1]-[2]. Efforts to improve problem-solving skills can be done through learning, one of which is through learning mathematics. In learning mathematics, problem-solving skills are useful for developing students' ideas to find solutions to mathematical problems. One of the topics in mathematics learning that can be used to improve mathematical problem-solving skills is the set topic [3]-[4]. In the set topic, students must understand and understand the problems presented in the problem, so they can think of the right solution by using problem-solving skills.

Many studies reveal that students' ability to solve mathematical problems in general is still low. This is also revealed from the results of tests conducted by two international studies, PISA and TIMSS, which explain that the problem-solving abilities of Indonesian students are still low [5]-[1]-[6]. Based on the results of observations that have been made at Madrasah Aliyah Negeri 2 Jambi City, where the results of the interviews explain that students have difficulty solving mathematical problems. Students have difficulty in solving mathematical problems given by the teacher.

The success of students in solving problems in mathematics cannot be separated from their metacognitive ability [7]-[8]. Metacognition is defined as one's knowledge, awareness, and control over thought processes and outcomes [9]-[10]. Without involving metacognition, students tend not to be able to choose solutions for problems [11]. Metacognition can improve math problem solving skills [12]. Students who have high metacognitive abilities tend to have good problem solving abilities, thus, it can be interpreted that the better the students' metacognition, the better their problem solving abilities [2]-[5].

However, not all students use their metacognitive abilities in solving mathematical problems, only a small number of students can use their metacognitive abilities in solving mathematical problems [13]. This explains that problem solving ability has a positive relationship with metacognitive ability. By paying attention to students' metacognitive abilities in solving mathematical problems, teachers can get an idea of how students' problem solving abilities are, and seek appropriate treatment to improve problem solving abilities [14]-[15]. Considering the importance of mastering problem-solving skills, the researchers conducted an analysis related to the profile of students' problem-solving abilities at Madrasah Aliyah Negeri 2 Jambi based on their metacognitive abilities. This study will also reveal what metacognitive activities appear when students solve math problems.

\section{METHOD}

This research is a Mix Methods research. Mix Methods approach is a research approach that combines a qualitative research and quantitative research. Quantitative research is a study whose data analysis process is carried out statistically [16]. While qualitative research is research that describes what, why, and how something can happen. The resulting data is presented in the form of words, numbers, and pictures [18]. This type of research is The Explanatory Sequential Design, which is a research that uses qualitative data analysis to interpret the quantitative data that has been collected. Figure 1 shows the procedures carried out in this study. 


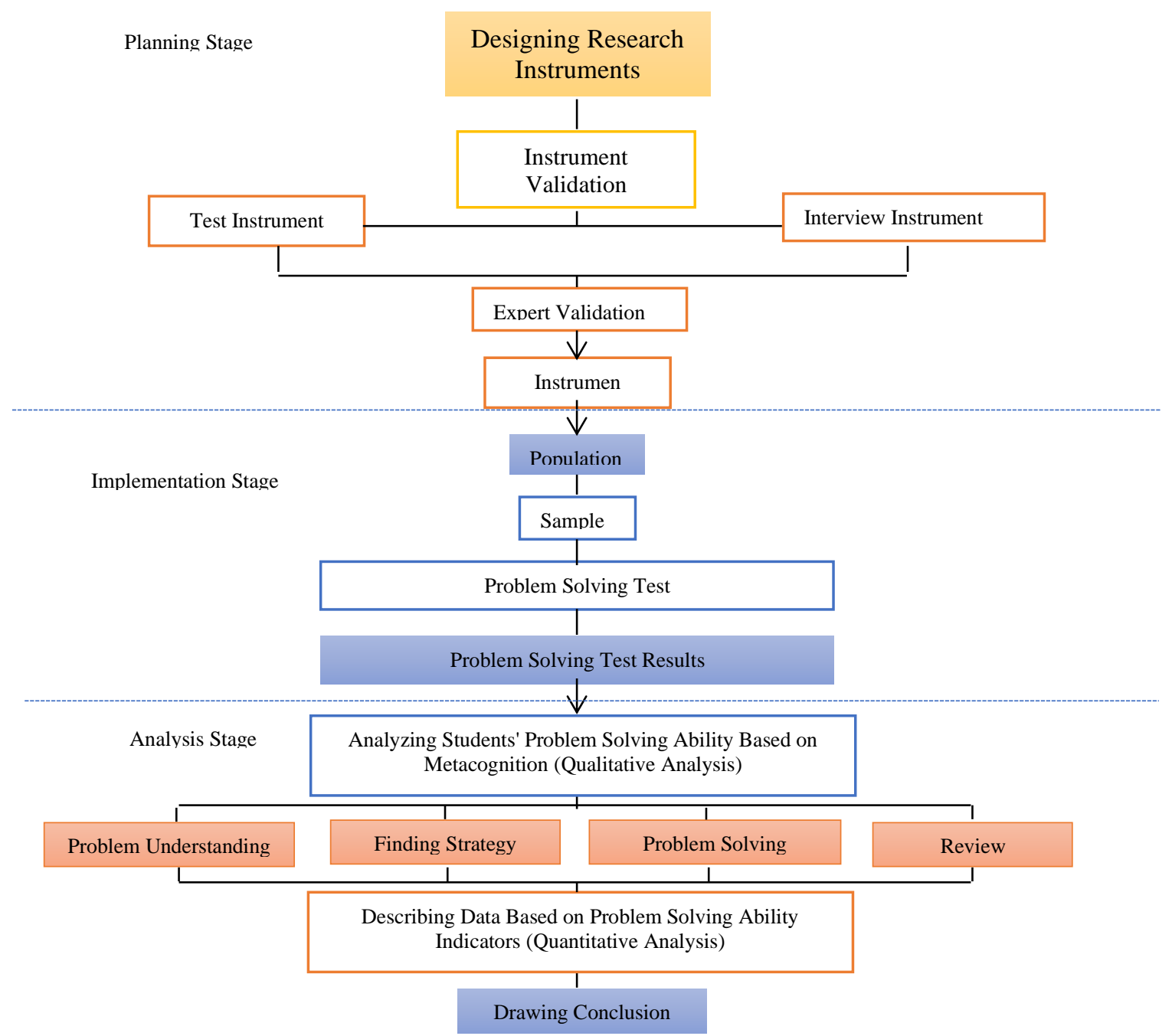

Figure 1. Research Procedure

In this study, there is one class that will be sampled. The sample will be given a problem-solving ability test. An effective way to measure students' problem solving abilities is through tests that are adjusted to problem solving indicators [16]-[17]. To strengthen the test result data, interviews were conducted related to metacognitive abilities in solving the given problems. The sample in this study was selected using the Simple Random Sampling technique [17]-[19]. The research sample was selected from the research population. The population in this study was class XII Madrasah Aliyah Negeri 2 Jambi City in the 2020/2021 academic year. The research subjects were students of class XII MIA 2 (Natural Science Major) with a total of 25 students. Selected subjects are then given test questions and interviews[20]. The instrument used in this study is a mathematical problem on a set topic to measure the indicators of students' problem solving abilities.

\section{RESULTS AND DISCUSSION}

The treatment given to the research subject is through giving problem solving test questions. The indicator of problem solving ability refers to the problem solving steps according to Polya which consists of four steps, including: 1) The first indicator is understanding, in this stage, we measured students' ability to analyze information on the given problem, as well as analyze the questions in the problem. ; 2) The second indicator 
is planning for problem solving. In this stage, we measured the subject's ability to identify appropriate problem-solving strategies to solve the problem; 3) The third indicator is to implement the problem-solving plan. In this stage, we measured the subject's ability to carry out the completion according to the plan that has been prepared; 4)The fourth indicator is to re-check. In this stage, we observed whether the subject re-checks the work that has been done or not.

Table 1. Problem Solving Ability Test Scoring Guidelines

\begin{tabular}{|c|c|c|}
\hline $\begin{array}{l}\text { Problem Solving } \\
\text { Indicators }\end{array}$ & Students' Acitivities & Score \\
\hline \multirow[t]{10}{*}{$\begin{array}{l}\text { Understanding the } \\
\text { Problem }\end{array}$} & $\begin{array}{l}\text { Students write down the information they get from the } \\
\text { questions/problems: }\end{array}$ & \\
\hline & Students do not write things that are known & 0 \\
\hline & Students write down the information but it's wrong & 1 \\
\hline & Students write down information but it is incomplete & 2 \\
\hline & Students write information completely and correctly & 3 \\
\hline & Students write down information from the questions/problems: & \\
\hline & Students do not write down the information asked & 0 \\
\hline & Students write down the information that is asked but it is wrong & 1 \\
\hline & Students, the information asked is incomplete & 2 \\
\hline & Students write down the information asked completely and correctly & 3 \\
\hline Planning for & Students do not make a solution plan for the solution & 0 \\
\hline \multirow[t]{3}{*}{ Problem Solving } & Learners make plans for solving solutions but lead to wrong answers & 1 \\
\hline & $\begin{array}{l}\text { Learners make a solution plan of completion that leads to correct but } \\
\text { incomplete answers }\end{array}$ & 2 \\
\hline & $\begin{array}{l}\text { Students make a complete solution plan and lead to the correct } \\
\text { answer }\end{array}$ & 3 \\
\hline Implementing the & Students do not write down solutions & 0 \\
\hline \multirow[t]{3}{*}{ Plan } & Students write a solution but with an unclear procedure & 1 \\
\hline & $\begin{array}{l}\text { Students write a solution procedure that leads to the correct answer } \\
\text { but writes the wrong solution }\end{array}$ & 2 \\
\hline & $\begin{array}{l}\text { Students write the correct solution procedure and get the correct } \\
\text { result }\end{array}$ & 3 \\
\hline \multirow[t]{5}{*}{ Re-checkk } & Students do not write down the solution to the question/problem & 0 \\
\hline & Students solve question/problem incorrectly & 1 \\
\hline & Students complete the question/problem incompletely & 2 \\
\hline & $\begin{array}{l}\text { Students write down the solution of the question/problem completely } \\
\text { and correctly }\end{array}$ & 3 \\
\hline & Maximum Score & 15 \\
\hline
\end{tabular}

Not all students can solve problems using Polya's problem-solving steps. The highest score of students' problem-solving ability is 13 with details: on the understanding indicator, the student could write well the information from the question completely and correctly and wrote down the things asked in the question completely and correctly. In the planning indicator, students could make a complete solution plan and lead to the correct answer. In the implementation indicator, students could write a completion procedure that leads to the correct answer but wrong in completion. In evaluating indicators or re-checking, students could solve the questions given but are not correct.

The lowest student problem-solving ability score is 0 , where there are several students who scored 0 . Based on the analysis of the answers of a student who scored 0 , it was found that on the understanding indicator, the student could not write down the known information and the information asked. In the planning indicator, the student could not make a solution plan for the completion, in the implementation indicator, the student could not write the solution correctly, and in the re-check indicator, the student did not re-check 
the solution that has been given. Clearer information regarding each student's score is shown in Table 2.

Table 2. Student Problem Solving Ability Score

\begin{tabular}{|c|c|c|c|c|c|}
\hline \multirow{2}{*}{$\begin{array}{c}\text { Subject } \\
\text { Code }\end{array}$} & \multicolumn{4}{|c|}{ Score } & \multirow{2}{*}{$\begin{array}{l}\text { Total } \\
\text { Score }\end{array}$} \\
\hline & Indicator I & Indicator II & Indicator III & Indicator IV & \\
\hline S1 & 6 & 1 & 1 & 0 & 8 \\
\hline $\mathrm{S} 2$ & 2 & 0 & 0 & 1 & 3 \\
\hline S3 & 6 & 2 & 1 & 1 & 10 \\
\hline S4 & 3 & 0 & 0 & 0 & 3 \\
\hline S5 & 2 & 0 & 0 & 0 & 2 \\
\hline S6 & 6 & 0 & 0 & 0 & 6 \\
\hline S7 & 6 & 3 & 2 & 2 & 13 \\
\hline S8 & 6 & 0 & 0 & 0 & 6 \\
\hline S9 & 2 & 0 & 0 & 0 & 2 \\
\hline $\mathrm{S} 10$ & 3 & 0 & 0 & 1 & 4 \\
\hline S11 & 4 & 1 & 2 & 1 & 8 \\
\hline $\mathrm{S} 12$ & 6 & 2 & 1 & 1 & 10 \\
\hline S13 & 6 & 1 & 2 & 1 & 10 \\
\hline S14 & 2 & 0 & 0 & 0 & 2 \\
\hline S15 & 6 & 0 & 1 & 0 & 7 \\
\hline S16 & 5 & 1 & 0 & 1 & 7 \\
\hline S17 & 4 & 1 & 0 & 0 & 5 \\
\hline S18 & 2 & 1 & 1 & 1 & 5 \\
\hline S19 & 6 & 0 & 0 & 0 & 6 \\
\hline S20 & 6 & 3 & 2 & 1 & 12 \\
\hline S21 & 6 & 0 & 0 & 0 & 6 \\
\hline S22 & 2 & 0 & 0 & 1 & 3 \\
\hline S23 & 3 & 0 & 0 & 0 & 3 \\
\hline S24 & 6 & 2 & 2 & 2 & 12 \\
\hline S25 & 5 & 0 & 2 & 0 & 7 \\
\hline
\end{tabular}

Based on the test results, students' problem-solving abilities are divided into 3 categories. The categories are students with high, moderate, and low problem-solving abilities. The number of subjects who meet each category of problem-solving abilities can be seen in the Table 3:

Table 3. Category of Student Problem Solving Ability Test Results

\begin{tabular}{cccc}
\hline Category & Criteria & Total & Percentage \\
\hline High & $\mathrm{X} \geq 10$ & 6 & $24 \%$ \\
Moderate & $5 \leq \mathrm{X}<10$ & 11 & $44 \%$ \\
Low & $\mathrm{X}<5$ & 8 & $32 \%$ \\
\hline
\end{tabular}

The test results also show how the level of students' ability to solve the given problem is based on Polya's problem-solving ability indicators. The ability of students to understand the questions that have been given can be seen in the diagram in Figure 2 below: 


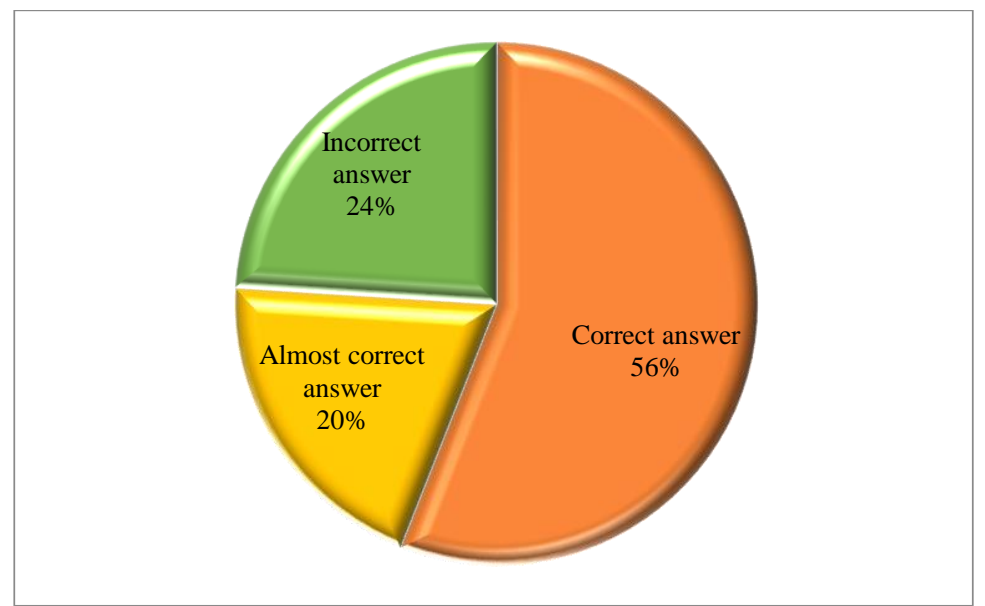

Figure 2. Indicator of Understanding the Problem

Students who answered correctly, could write down the information in the questions correctly, and wrote down the information asked in the questions correctly are said to have met the understanding indicator. Students who answered almost correctly tend to make mistakes in writing down the information in the questions and the information asked in the questions. Meanwhile, students who answered incorrectly were students who made mistakes in writing down the known information and the information asked in the questions. After that, students did planning solutions to answer the given questions. At this stage, the results of planning indicators can be seen in the following diagram:

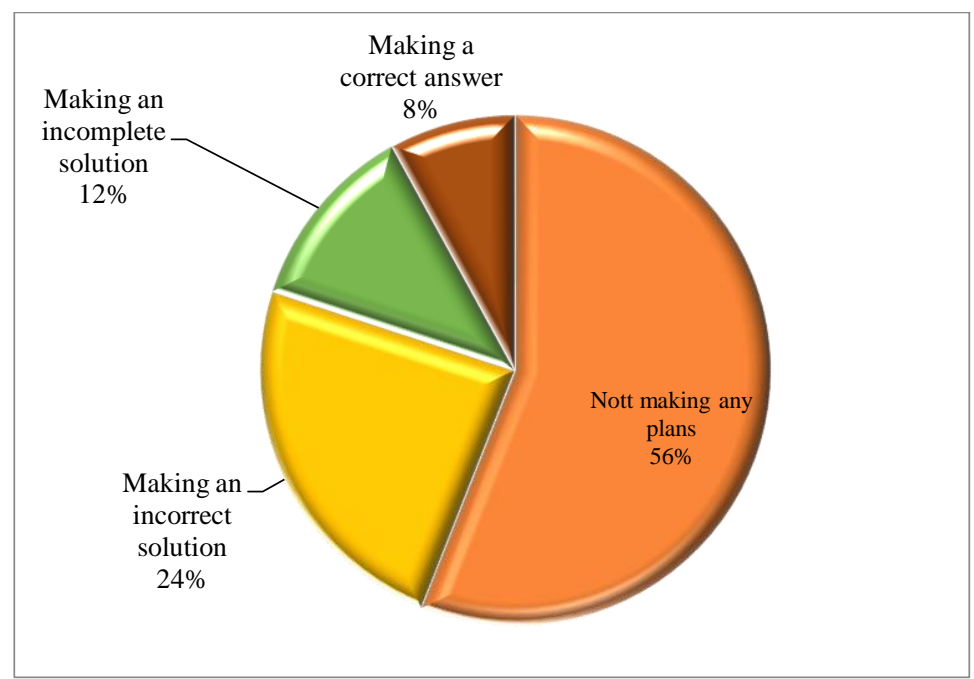

Figure 3. Indicator of Planning the Solution

At this stage, only $8 \%$ of all studentsouldan make an answer plan correctly. The word 'plan' means that students plan solutions in a structured way starting from writing down what is known and what is asked in the problem. Then, students analyze and determine the right solution to use. Meanwhile, students who made incomplete solution plans were students who wrote the wrong solution to answer the questions, in this case there were $12 \%$ of students who answered incompletely. Students who made incorrect answer plans were students who wrotee information that is known and the information asked incorrectly and wrote the completion solution incorrectly, in this case $24 \%$ of students answer incorrectly. Meanwhile, students who did not make plans were students who answered the questions 
by guessing, in this case $56 \%$ of students did it. After students make plans, the next step is implementing the plans that have been prepared. This can be seen in Figure 4:

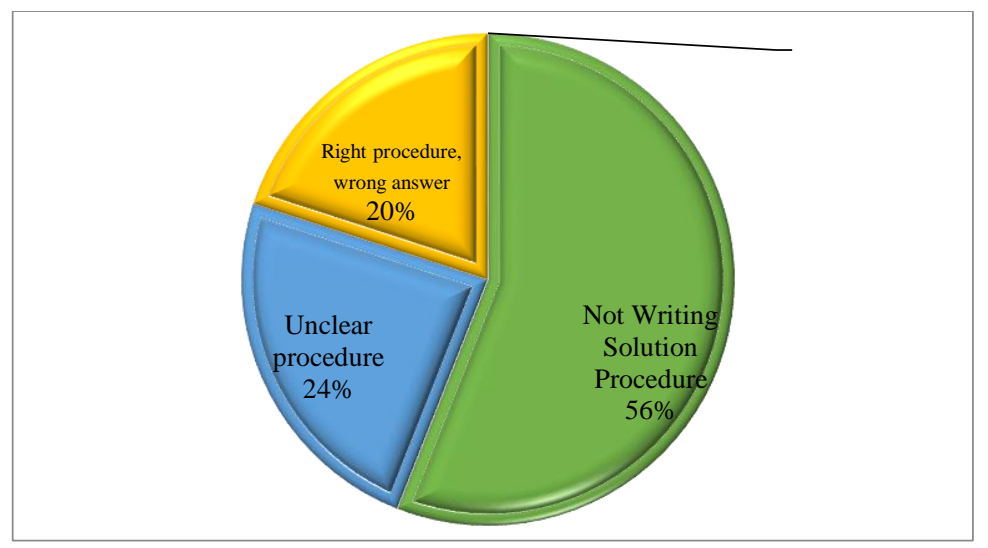

Figure 4. Implementation Indicator

At this stage, dominated by students who did not write down the solution at all, $56 \%$ of students did this. The students explained the reason for not writing down the solution was because they made a mistake in determining the formula at the planning stage, so, when time ran out, the student did not write down the solution. There are $20 \%$ of students who wrote the procedure correctly but the answer was wrong. These students have written the steps of the solution correctly (write down what is known and what is asked and use the right formula). However, they made an error in the calculation so that the results obtained were incorrect, inaccuracy was a contributing factor. While there are $24 \%$ of students wrote the procedure unclearly, they answered the questions only by guessing. The next step was to re-check. These stages can be seen in Figure 5.

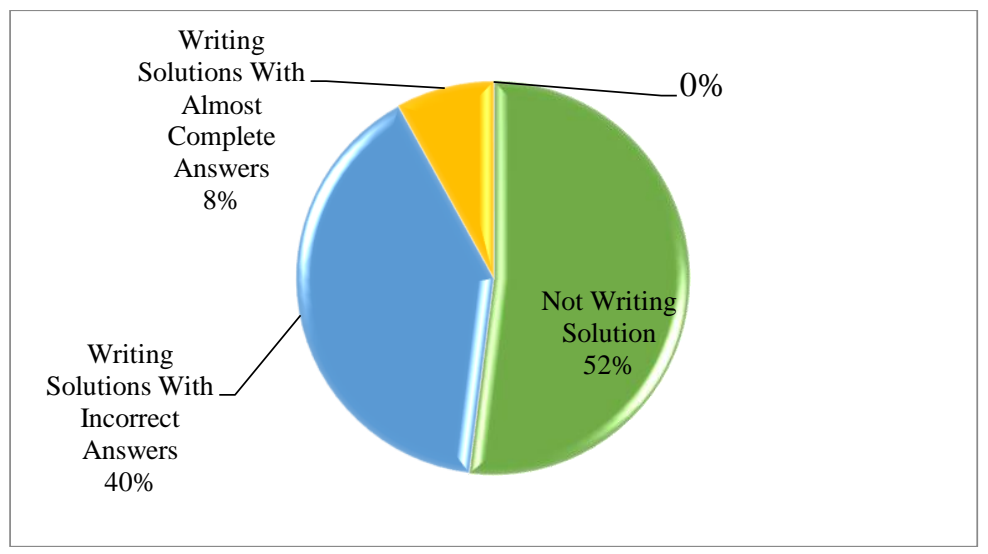

Figure 5. Indicator of Evaluation (Re-check)

At this stage, there were $8 \%$ of students with almost complete answers, $40 \%$ of students with incorrect answers, and $52 \%$ of students who did not write a solution at all..

After obtaining test results related to problem solving abilities, the research was continued by conducting interviews with research subjects with the aim of finding more in-depth information related to students' metacognitive abilities in solving problems. The results of the interviews illustrate how students' problem solving abilities are based on students' own metacognition. Basically, students' metacognitive activities that appear in interviews are different. These metacognitive activities include aspects of awareness, 
evaluation, and regulation. These aspects are closely related to students' problem solving abilities. The description of the interview results can be seen in Figure 6:

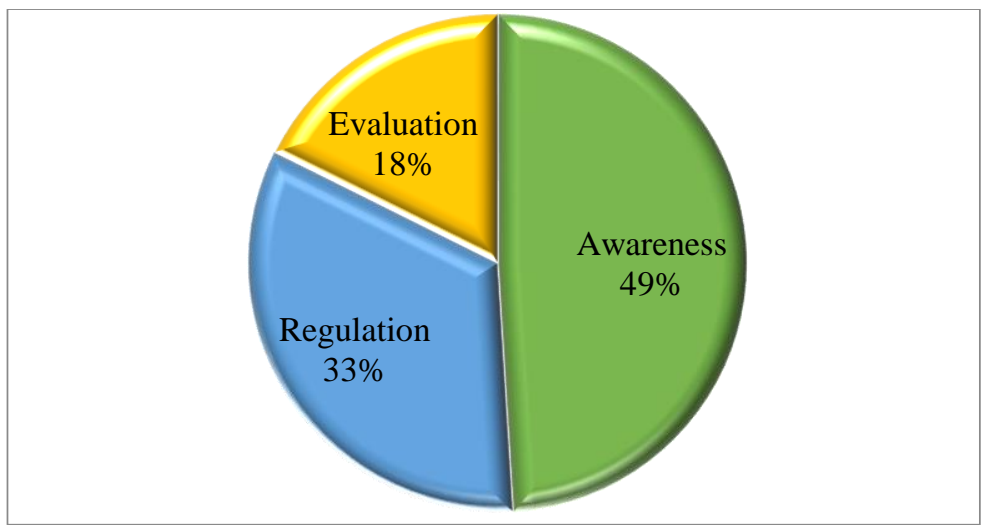

Figure 6. Problem Solving Ability Based on Metacognition

Based on the results of the study, it can be described how the level of students' problem-solving abilities based on the students' metacognition. Students' problem solving abilities based on metacognition are categorized as good. Students could plan problem solving solutions well, students could apply the lessons they have learned to solving problems, students could implement strategies/plans that they have compiled themselves. Students with high metacognition could even solve the problems given at all stages well. Awareness is an aspect that appears in each subject when solving problems. Meanwhile, not all aspects of regulation and evaluation appear when the subject solves the problem. The results of other studies also explain that learning by involving metacognitive can produce better results in solving mathematical problems [21]. Moreover, the aspect of students' metacognition activities also describes how students' problem-solving abilities are in solving problems. The results of the interviews also illustrate how students carry out the process of solving the problems. Metacognitive activities that arise when students solve problems are awareness, regulation, and evaluation [22].

\section{CONCLUSION}

Based on the results of the study, it can be illustrated that the problem-solving abilities of the research subjects are in the good category. Students can solve problems well. In solving problems, students use Polya's problem-solving steps. Although not all students can use Polya's steps in solving problems well. Students' problem solving abilities based on metacognition are categorized as good. This can be seen through interviews to find out how the process carried out by these students in answering or solving questions. The students' metacognitive activities that are seen in solving mathematical problems are awareness, regulation, and evaluation. The awreness aspect is the aspect that most often appears when students solve the problem, followed by the regulatory aspect, and the one that appears the least is the evaluation aspect.

\section{REFERENCES}

[1] D. Rahmawati, S. Sajidan, dan A. Ashadi, "Analysis of problem solving skill in learning biology at senior high school of Surakarta," Journal of Physics: Conference Series, vol. 1006, no. 1, 2018, doi: 10.1088/1742-6596/1006/1/012014.

[2] R. Rustanuarsi, A. Mirza, dan Hamdani, "Proses pemecahan masalah dalam materi aritmatika sosial berdasarkan metakognisi siswa smp," hal. 1-12, 2015.

[3] A. Yarmayani, "Analisis Kemampuan Pemecahan Masalah Matematis Siswa Kelas 
Xi Mipa Sma Negeri 1 Kota Jambi," Jurnal Ilmiah Dikdaya, vol. 6, no. 2, hal. 12 19, 2016.

[4] U. Sholihah, "Membangun metakognisi siswa dalam memecahkan masalah matematika," vol. 04, no. 46, hal. 83-100, 2016.

[5] Wahyuddin, "Pengaruh Metakognisi, Motivasi Belajar, dan Kreativitas belajar terhadap Kemampuan Pemecahan Masalah Siswa Kelas VIII SMP Negeri 2 Sabbangparu Kabupaten Wajo," Jurnal Daya Matematis, vol. 4, no. 1, hal. 72-83, 2016.

[6] S. K. Jua, Sarwanto, dan Sukarmin, "The profile of students' problem-solving skill in physics across interest program in the secondary school," Journal of Physics: Conference Series, vol. 1022, no. 1, 2018, doi: 10.1088/1742-6596/1022/1/012027.

[7] A. Mustamin, "Pelibatan Metakognisi Dalam Pemecahan Masalah Matematika," Edumatica, vol. 01, no. April, hal. 25-32, 2011.

[8] B. Mustofa, "Implementasi Pembelajaran Kontruktivistik dalam Membentuk Siswa yang Ulul Albab di Madrasah Aliyah Negeri 2 Tulungagung," IAIN Tulungagung, 2016.

[9] R. Khairunnisa dan N. Setyaningsih, "Analisis Metakognisi Siswa dalam Pemecahan Masalah Aritmatika Sosial Ditinjau dari Perbedaan Gender," no. Knpmp Ii, hal. 465-474, 2017.

[10] V. R. Bulu, Budiyono, dan S. Isnandar, "Peluang Ditinjau dari Tipe Kepribadian Tipologi Hippocrates - Galenus Kelas XI MIA 1 SMA Negeri I," Jurnal Elektronik Pembelajaran Matematika, vol. 3, no. 9, hal. 970-984, 2015.

[11] A. Yimer dan F. N. Ellerton, "Cognitive and Metacognitive Aspects of Mathematical Problem Solving: An Emerging Model," no. 1994, hal. 575-582, 2001

[12] T. Thayeb dan A. P. Putri, "Kemampuan Metakognisi Untuk Meningkatkan Keterampilan Pemecahan Masalah Matematika Siswa Kelas Viii B Mts Madani Alauddin Paopao Kabupaten Gowa," Jurnal Matematika dan Pembelajaran, vol. 5, no. 1, hal. 1-17, 2017, doi: 10.24252/mapan.2017v5n1a1.

[13] D. Purnomo, T. Nusantara, dan S. Rahardjo, "Kata Kunci: metakognisi, diskusi kelompok, pembelajaran matematika," no. 1988, 2014.

[14] Kamid, "Metakognisi Siswa Dalam Menyelesaikan Soal Matematika (Studi Kasus Pada Siswa SMP Berdasarkan Gender)," vol. 03, no. April, hal. 64-72, 2013.

[15] A. S. Pratama, "Analisis Pemecahan Masalah Berbasis Metakognitif," 2019.

[16] S. Siyutko dan A. Sodik, Dasar Metodologi Penelitian, vol. 11, no. 3. Yogyakarta: Literasi Media, 2015.

[17] H. Tan, "Kemampuan Pemecahan Masalah Matematika," no. May, 2019.

[18] R. Ananda dan M. Fadhil, Statistik Pendidikan: Teori dan Praktik dalam Pendidikan', Cetakan Pe. Medan: CV. Widya Puspita, 2018.

[19] Suryana, "Metodologi Penelitian Model Prakatis Penelitian Kuantitatif dan Kualitatif," Universitas Pendidikan Indonesia, hal. 1-243, 2012, doi: 10.1007/s13398-014-0173-7.2.

[20] Hardani dkk., Metode Penelitian Kualitatif \& Kuantitatif, no. April. Pustaka Ilmu Group, 2020.

[21] J. Ibrahim, "The Effect of Cooperative Learning with Metacognitive Scaffolding on Mathematics Conceptual Understanding and Procedural Fluency," Journal International, no. 32, 2012.

[22] M. T. Magiera dan S. J. Zawojewski, "Characterizations of Social-Based and SelfBased Contexts Associated With Students' Awareness, Evaluation, and 
Regulation of Their Thinking During Small-Group Mathematical Modeling," Journal on Mathematics Education, vol. 42, no. 5, hal. 486-520, 2015. 